\title{
Physicochemical and microbiological stability of mixed nectar of orange and uvaia
}

\author{
Karla Silva Tomaz ${ }^{1}$ Mayara Rodrigues da Silva Ferreira ${ }^{1}$ Mércia da Silva Mesquita ${ }^{1}$ \\ José Humberto de Oliveira Filho ${ }^{1^{*}}$
}

\author{
${ }_{1}^{1}$ Instituto Federal de Educação, Ciência e Tecnologia do Triângulo Mineiro (IFTM), 38064-790, Uberaba, MG, Brasil. E-mail: josehumberto@iftm.edu.br \\ ${ }^{*}$ Corresponding author.
}

\begin{abstract}
The addition of Cerrado fruits to juice and nectar formulations is an interesting alternative for the beverage industry, as it allows developing innovative products containing nutritive and bioactive compounds. Thus, the objective of this study was to produce mixed nectar of orange and uvaia, using orange nectar as a control, and to evaluate physicochemical and microbiological characteristics of beverages during the storage. Mixed nectar formulations were prepared with the addition of uvaia pulp and orange juice, while the orange nectar was made with fruit juice, and the addition of mineral water and commercial sucrose. Resulting nectar was bottled in sterilized glass bottles, immediately closed and heat-treated in a water bath at $90{ }^{\circ} \mathrm{C}$ for 5 minutes. Then, bottles containing the beverages were cooled and stored at room temperature for the physicochemical (Brix, pH, total acidity, ascorbic acid, reducing sugars, and phenolic compounds) and microbiological (total coliforms, molds and yeasts, and lactic acid bacteria) characterization. Total soluble solids and reducing sugars contents increased during storage for the mixed nectar formulations. Higher total acidity and lower pH levels were observed for the mixed nectar throughout the storage. Although, the mixed nectar exhibited higher ascorbic acid content, this parameter was significantly reduced during the storage. Concentration of phenolic compounds was higher for the mixed nectar, which increased with the addition of uvaia pulp to the formulation. Lactic acid bacteria counts remained at reduced levels for all formulations analyzed, while yeasts and total coliforms populations increased in the control formulation during the storage.
\end{abstract}

Key words: beverage, fruit, storage, nectar.

Estabilidade físico-química e microbiológica de néctar misto de laranja e uvaia

RESUMO: A introdução de frutos do cerrado em sucos e néctares é uma alternativa interessante para as indústrias de bebidas, pois permite desenvolver produtos inovadores, com importantes fontes nutritivas e bioativas. Assim, o objetivo deste estudo foi elaborar formulações de néctar misto de laranja e uvaia e uma formulação de néctar de laranja (controle), para então serem avaliadas as características fỉsico-químicas e microbiológicas das bebidas, durante o periodo de armazenamento do produto. As formulações de néctar misto foram preparadas com adição de polpa de uvaia e suco de laranja, enquanto o néctar de laranja foi elaborado com o suco da fruta, sendo adicionados água mineral e sacarose comercial na composição de cada produto. O néctar resultante de cada tratamento foi envasado em garrafas de vidro esterilizadas, sendo imediatamente tampadas e submetidas a um tratamento térmico em banho-maria a $90{ }^{\circ} \mathrm{C}$ por 5 minutos. Posteriormente, as embalagens foram resfriadas e armazenadas a temperatura ambiente para a determinação das características físico-químicas (Brix, pH, acidez total, ácido ascórbico, açúcares redutores e compostos fenólicos) e microbiológicas (coliformes totais, bolores e leveduras e bactérias láticas) da bebida. $O$ teor de sólidos solúveis totais e a porcentagem de açúcares redutores foram maiores durante o armazenamento, para o néctar misto com maior proporção de uvaia. Observou-se maiores valores de acidez total e menor pH para o néctar misto ao longo do armazenamento. O néctar misto apresentou maiores concentrações de ácido ascórbico, entretanto, este parâmetro foi significativamente reduzido durante o período de estocagem. A concentração de compostos fenólicos foi superior para o néctar misto, sendo esta, porporcional a adição de polpa de uvaia na composição da bebida. As contagens de bactérias láticas manteve-se a níveis reduzidos para todas as formulações analisadas, enquanto as populações de bolores e leveduras e coliformes totais foram aumentadas durante o armazenamento para a formulação controle.

Palavras-chave: bebida, frutas, armazenamento, néctar.

\section{INTRODUCTION}

The addition of Cerrado fruits to juice and nectar formulations is an interesting alternative for the beverage industry, since it allows developing innovative products with different sensory characteristics, besides contributing with the incorporation of nutritive and bioactive compounds in foods (MATSUURA; ROLIM, 2002; NEVES et al., 2011; MORZELLE et al., 2011).
The fruits of the Brazilian Cerrado contain a great variety of bioactive compounds (phenolic compounds, carotenoids, vitamins, minerals, and dietary fibers), making the fruits relevant for both consumption in natura and industrial processing. In this context, uvaia (Eugenia uvalha Cambess) stands out, which grows in the states of Rio Grande do Sul, Paraná, Santa Catarina, São Paulo, and Minas Gerais, consisting of edible fruits of yellow or orange color, capable to be used in the manufacture of soft drinks, ice cream, and jams. (REITZ et al., 1988; SILVA et al., 2008; GOMES, 2012). 
Concentration of phenolic compounds in uvaia is higher when compared to many Brazilian fruits such as tamarind, passion fruit, papaya, pineapple, mango and cashew (RUFINO et al., 2010; SILVA et al., 2014). These compounds have a high capacity to sequester free radicals, and can contribute to the reduction of oxidative stress and the increase of the antioxidant defense mechanism, aiding in the prevention and treatment of many chronic diseases (RUFINO et al., 2009; RUFINO et al 2010; GUERRA et al, 2011; LOPES et al, 2018). Moreover, its unique composition, associated to its size, shape, and peel color, can contribute to a greater acceptance of the fruit in the consumer market (SCALON et al., 2004; ZILLO et al., 2013)

Considering the prominent position of Brazil in the industrialization of orange juice and the cultivation of this fruit (NEVES et al., 2010), along with the current trend towards the consumption of exotic fruits and the improvement of the techniques of production, transport, and marketing, uvaia (Eugenia pyriformis Cambess) has a great technological potential for the production of an orange-based mixed nectar.

Thus, to explore the potential of uvaia fruits for the development of an innovative nonalcoholic beverage, and considering the lack of information on the industrial processing of these fruits, the present research aimed to produce and evaluate the physicochemical and microbiological characteristics of mixed nectar of orange and uvaia during the storage period.

\section{MATERIAL AND METHODS}

Oranges were purchased from local market in Uberaba - MG, and the uvaia fruits were purchased from the Fruit Industry of the Federal Institute of Education, Science, and Technology of the Triângulo Mineiro (IFTM), at Uberaba campus. Commercial crystal sugar and mineral water were used in the production of the nectar.

The fruits were sent to the Fruit and Vegetable Processing Sector at IFTM, and selected for maturation stage and presence of injuries. Then, they were washed in running water, immersed in a sanitizing solution containing $100 \mathrm{ppm}$ of sodium hypochlorite for 5 minutes, and again washed in running water.

The orange juice was extracted in an electric juicer (6215 Philips Walita), and the uvaia fruits were pulped in a stainless steel brush type pulping machine $(0.25 \mathrm{df}$, Itametal) with a sieve of $1.0 \mathrm{~mm}$ of diameter.
The nectars containing $60 \%$ fruit pulp were formulated as the Brazilian legislation (BRASIL, 2013 ), in the following proportions: $60 \%$ orange juice (Formulation 1 - control); $40 \%$ orange juice $+20 \%$ uvaia pulp (Formulation 2); and 30\% orange juice + $30 \%$ uvaia pulp (Formulation 3), using mineral water and crystal sugar to standardize the total soluble solids at $15^{\circ}$ Brix, followed by stirring until complete homogenization.

The nectar formulations were bottled in 200 $\mathrm{mL}$ sterilized glass bottles, capped with plastic screw cap, and heat-treated at $90^{\circ} \mathrm{C}$ in a water bath for 5 minutes and then cooled in running water to $25^{\circ} \mathrm{C}$, and stored at room temperature for the physicochemical and microbiological characterization during $0,15,30$, and 45 days of storage.

For the physicochemical characterization of the raw materials and nectars, the following parameters were determined: total soluble solids (TSS) using a bench refractometer (AR200, Reichert), and the results expressed as Brix (IAL, 2008); total titratable acidity (TA) by titration of the sample with $0.1 \mathrm{~N} \mathrm{NaOH}$ and the results expressed as $\mathrm{g}$ citric acid. $100 \mathrm{~mL}^{-1}$ (IAL, 2008); and ascorbic acid according to the Tillmans method (2.6 dichlorophenol indophenol) and the results expressed as $\mathrm{mg}$ ascorbic acid . $100 \mathrm{~mL}^{-1}$ (IAL, 2008). The $\mathrm{pH}$ of the samples was measured in a potentiometer (TEC11, Tecnal). The TSS/TA ratio was calculated for both the orange juice and uvaia pulp by dividing the total soluble solids ( ${ }^{\circ}$ Brix) and the total titratable acidity values. The reducing sugars were determined according to the LANE \& EYNON method (1934) using a Redutec apparatus (Marconi), and the total phenolic compounds (FOLIN; CIOCALTEU, 1927) of the nectars were determined during the storage.

The most probable number (MPN) of coliforms at $35{ }^{\circ} \mathrm{C}$ was determined in the nectars using 2\% Brilliant Green Bile broth (VB); lactic acid bacteria were enumerated by standard plate counting using Man, Rogosa and Sharpe agar (MRS); and mold and yeasts were determined by standard plate counting using Dicloran Rosa Bengal Chloramphenicol agar (DRBC), as described by SILVA et al. (2007).

The experiment was conducted in a completely randomized design (CRD) in a $3 \times 4$ factorial scheme and three replicates, with the first factor corresponding to the nectar formulations $(60 \%$ orange juice - F1:control; $40 \%$ orange juice $+20 \%$ uvaia pulp - F2; and $30 \%$ orange juice $+30 \%$ uvaia pulp - F3), and the second factor corresponding to the storage time $(0,15,30$, and 45 days $)$.

Results were analyzed by analysis of variance, using the F test (ANOVA), and the means 
were compared by the Tukey's test, considering the level of significance of $5 \%(\mathrm{p}<0.05)$, using the statistical program Sisvar (FERREIRA, 2000).

\section{RESULTS AND DISCUSSION}

Uvaia pulp presented higher total acidity, soluble solids, and ascorbic acid levels, while the $\mathrm{Brix} / \mathrm{TA}$ ratio and $\mathrm{pH}$ were lower when compared to the orange nectar (Table 1). The ascorbic acid level in uvaia was $40 \%$ higher than that eported in orange, which is relevant for the technological and nutritional quality of the beverage. Although the higher acidity of the uvaia pulp may contribute to the inhibition of the microbial growth, this parameter can lead to a reduction of the Brix/TA ratio, besides affecting the sensory characteristics of the final product.

During the storage at room temperature, significant $(p<0.05)$ changes were observed in the nectars for the parameters Brix, $\mathrm{pH}$, total acidity, ascorbic acid, and reducing sugars, while the concentration of phenolic compounds differed statistically only among the treatments.

No significant differences were observed for the total soluble solids (TSS) of all formulations at the beginning of the storage. However, after the 15th day of storage, higher TSS values were observed in the formulations containing higher uvaia pulp concentrations, remaining constant for the nectar made without the addition of uvaia pulp (Figure 1). This result may be probably due to the water absorption by the solid constituents of uvaia, thus increasing the concentration of dissolved solids in the beverage.

The mixed nectar presented lower $\mathrm{pH}$ values when compared to the control formulation, due to the intrinsic characteristics of the uvaia pulp (Figure 2). During the 45 days of storage, little changes were observed for this parameter, which remained within an acidic range $<4.5$, which is a threshold value for the development of some spoilage and pathogenic microorganisms (FRANCO, LANDGRAF, 2008).

The total acidity was significantly higher $(p<0.05)$ in the mixed nectar, which increased with the increase in uvaia pulp concentration (Figure 3). During the storage period, the acidity moderately reduced for both treatments, with values higher than $0.8 \mathrm{~g} .100 \mathrm{~mL}^{-1}$ for the formulation containing higher uvaia pulp concentrations. According to BEDETTI et al. (2013), the maintenance of $\mathrm{pH}$ and acidity levels of cagaita nectar may have contributed to the oxidative stability of the product during storage. Thus, uvaia has a high technological potential for the production of nectars, once the oxidative reactions may intensify the darkening of the product, thus compromising its acceptance by consumers (MATTIETTO et al., 2007).

The ascorbic acid levels were significantly higher in the mixed nectar, with an increase with the higher concentration of uvaia pulp. The ascorbic acid level in the freshly prepared mixed nectar was $90 \%$ higher for the formulation $\mathrm{F} 3$ when compared to the control (Figure 4).

During the storage, a reduction of the ascorbic acid levels was observed for both treatments, showing a tendency to stabilize after the 30th day of storage. Despite this reduction, the ascorbic acid levels were higher for the mixed nectar (F2 and F3) after 45 days of storage (Figure 4). The stability of the ascorbic acid increases in acidic environments (BEDETTI et al., 2013), thus the typical acidity of the uvaia pulp may have contributed to the maintenance of higher ascorbic acid concentrations in the mixed nectar at the end of the storage.

DAUD et al. (2016) have reported the antioxidant, anti-inflammatory, anti-hypertensive, and lipid-lowering properties of ascorbic acid, which can act in the prevention of cancer, osteoporosis, ocular diseases, septisemia, and cardiovascular

Table 1 - Physicochemical characteristics of orange juice (Citrus sinensis L. Osbeck) and uvaia pulp (Eugenia pyriformis Cambess).

\begin{tabular}{lcc}
\hline Parameters & Orange juice & Uvaia pulp \\
\hline Titratable acidity (citric acid) & $0.58 \mathrm{~g} .100 \mathrm{~mL}^{-1}$ & $0.96 \mathrm{~g} .100 \mathrm{~mL}^{-1}$ \\
Total soluble solids - TSS ( ${ }^{\circ}$ Brix) & 7.9 & 9.9 \\
TSS/TA ratio & 13.62 & 10.31 \\
Ascorbic acid & $46.24 \mathrm{mg} .100 \mathrm{~mL}^{-1}$ & $76,66 \mathrm{mg}^{-100} \mathrm{~mL}^{-1}$ \\
$\mathrm{pH}$ & 3.81 & 2.93 \\
\hline
\end{tabular}

Ciência Rural, v.49, n.7, 2019. 


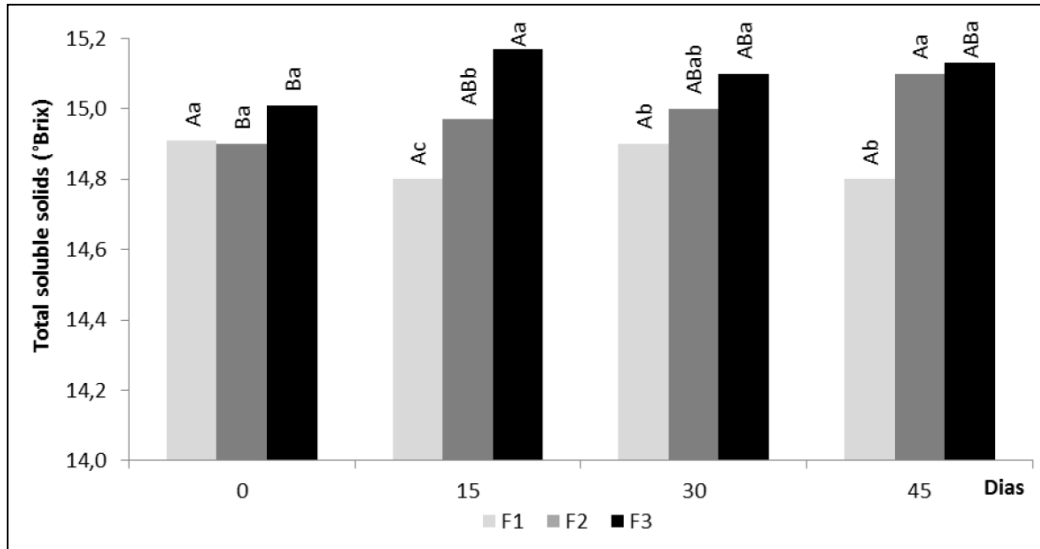

Figure 1 - Interaction between the storage time and the total soluble solids of the nectars. Lowercase letters compare averages between formulations at the same time. Uppercase letters compare averages of the same formulation at different times. $\mathrm{F} 1=60 \%$ orange juice; $\mathrm{F} 2=40 \%$ orange juice $+20 \%$ uvaia pulp; $\mathrm{F} 3=30 \%$ orange juice $+30 \%$ uvaia pulp.

diseases. In the present study, the addition of 20 to $30 \%$ of uvaia pulp to the nectar formulation led to the introduction of important sources of ascorbic acid into the beverage, thus contributing to the development of a product with relevant nutritive and bioactive properties.
No significant differences were observed for the reducing sugars concentration in the freshly prepared nectars; however, a considerable increase was observed in the mixed nectar after 15 days of storage, which was proportional to the increase in the uvaia pulp concentration (Figure 5).

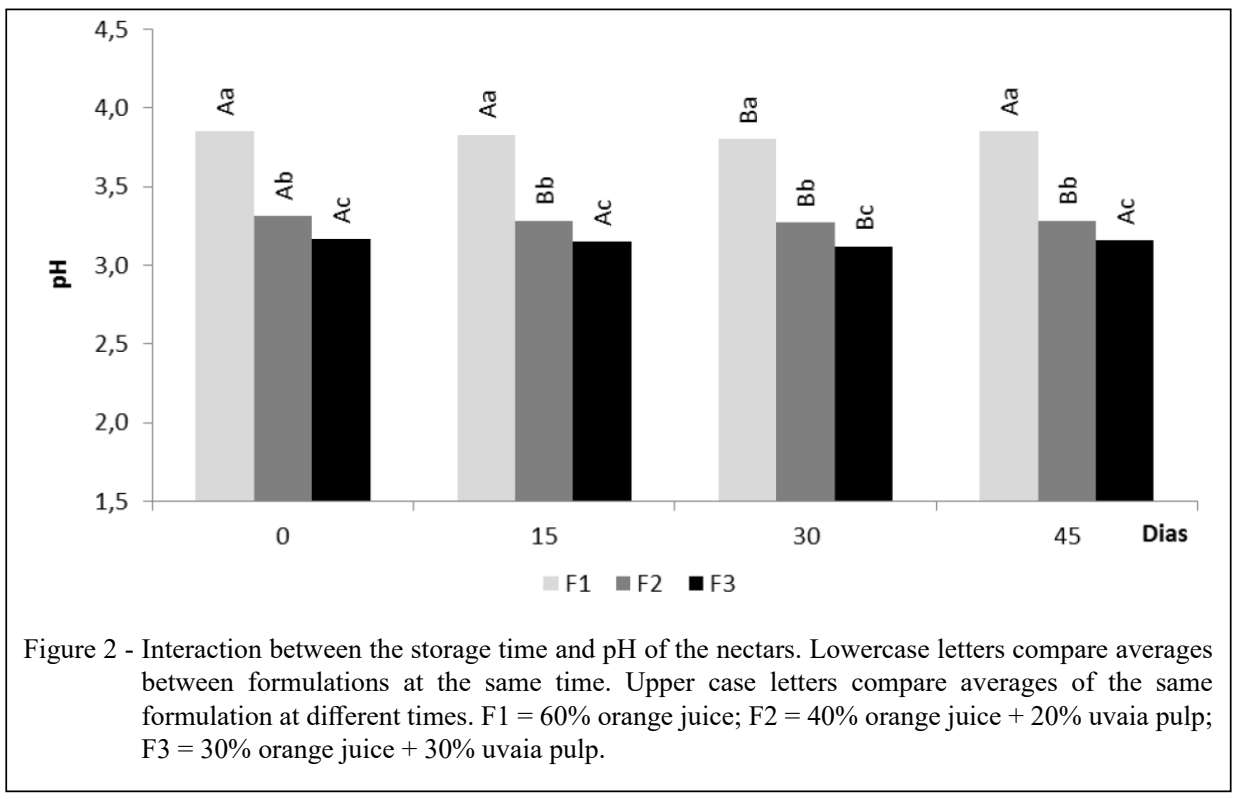

Ciência Rural, v.49, n.7, 2019. 


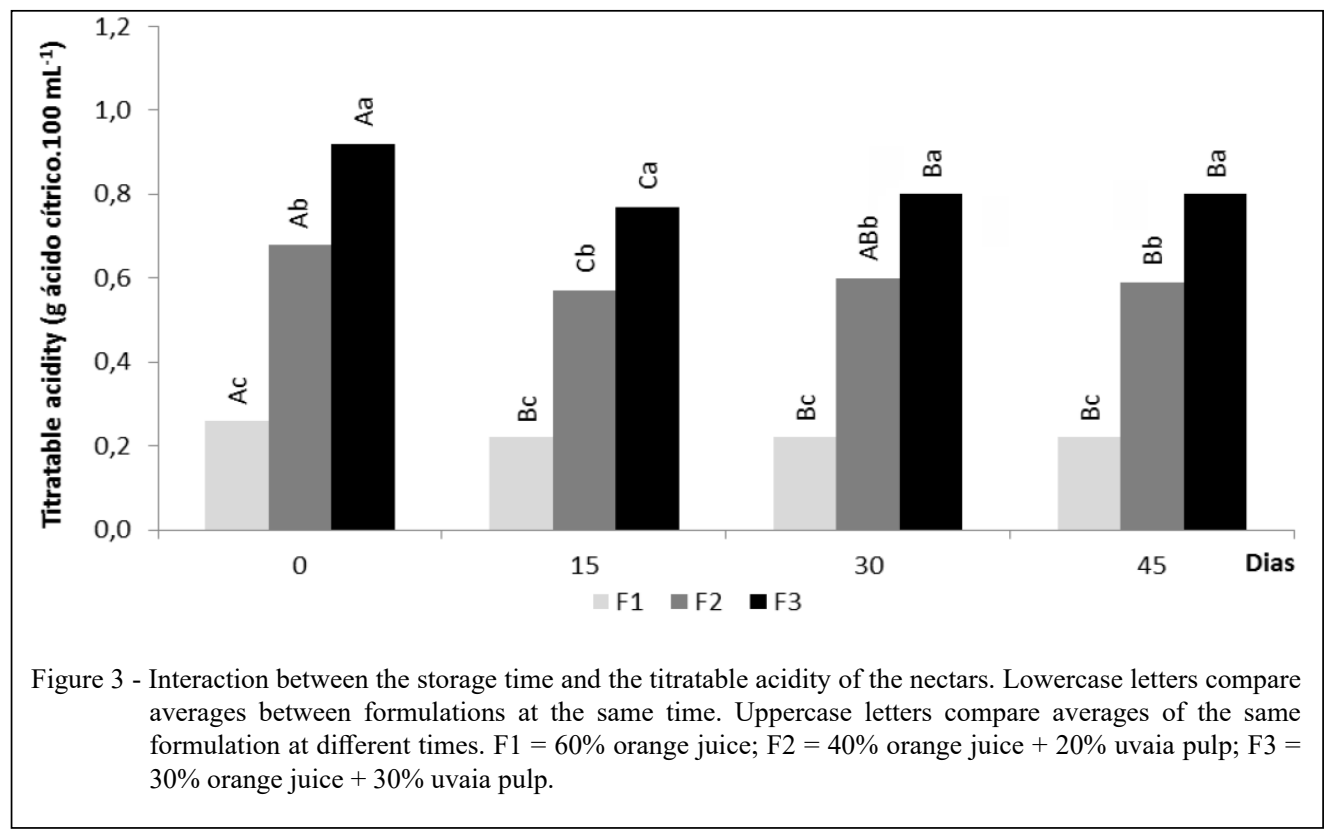

The higher acidity of the uvaia pulp, together with the heat treatment during pasteurization contributed to the sugar hydrolysis, increasing the reducing sugars in the mixed nectar during the storage. SANTOS et al. (2017) also reported higher acidity in mixed nectar of grape and ginger, resulting in an increase in reducing sugars contents in the final product, while SANTOS et al. (2010) reported that the pasteurization of cupuaçu nectar was responsible for the higher levels of reducing sugars in the beverage when compared to the fruit pulp.

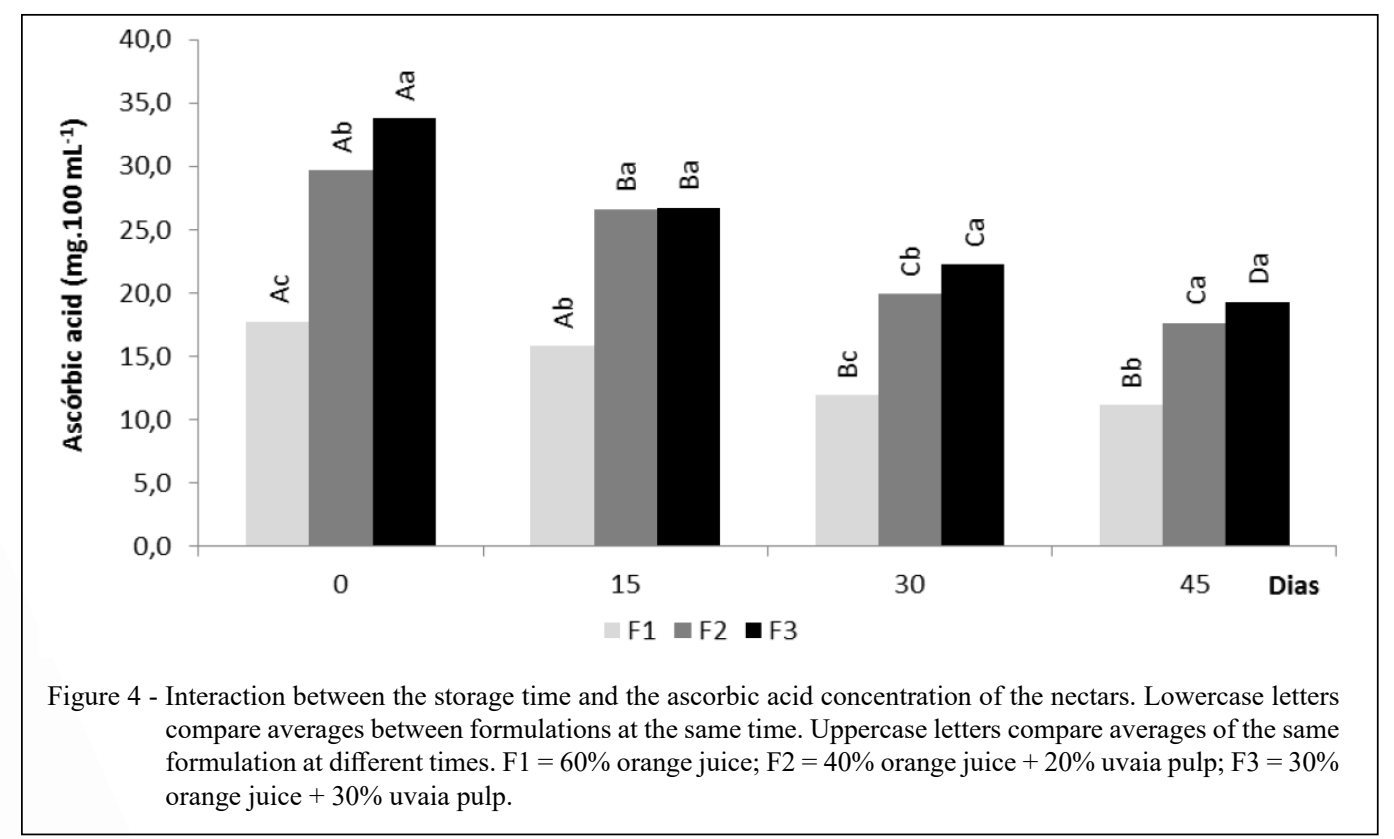

Ciência Rural, v.49, n.7, 2019. 


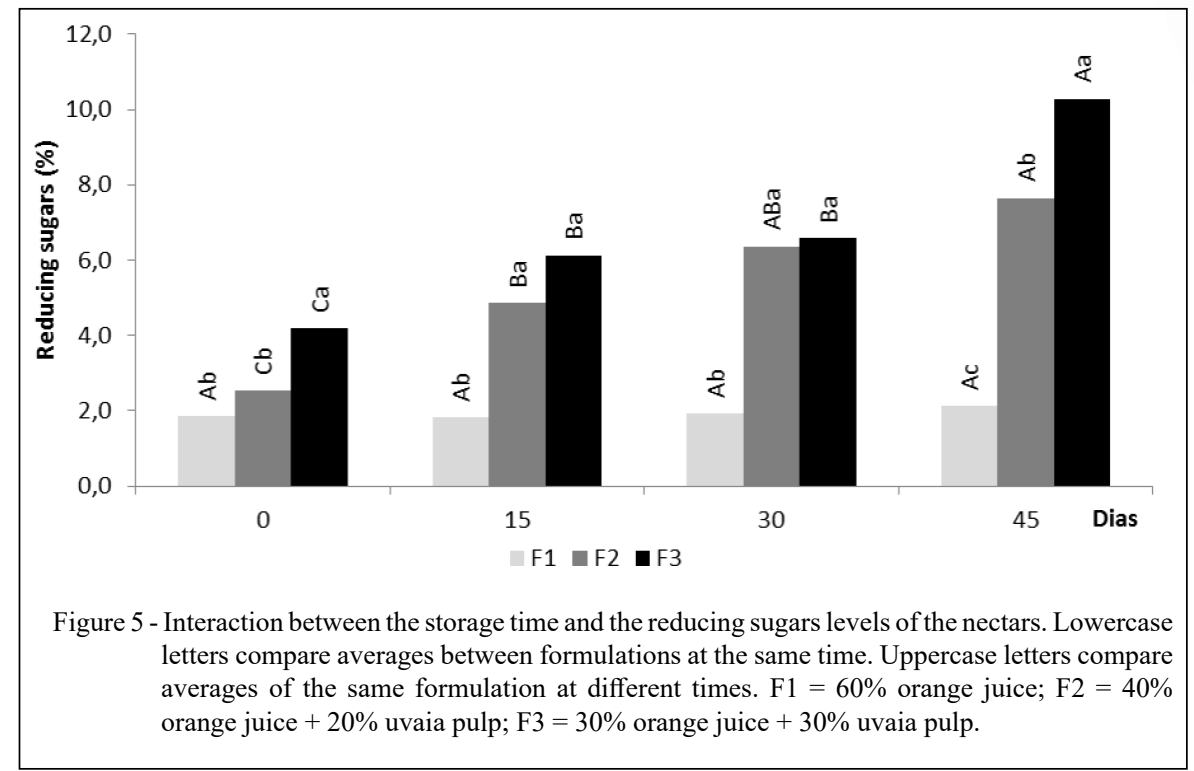

Significant $(p<0.05)$ differences were observed for the total phenolics contents among the formulations, with higher values for the mixed nectar, which increased with the increase in the uvaia pulp concentration (Table 2). The phenolic compounds have a direct relationship with the antioxidant capacity of many fruits, being responsible for the reduction and prevention of the oxidative processes, once they prevent the formation of free radicals, contributing with the inhibition and reduction of cellular lesions (KUSKOSKI et al., 2006; MAIA, 2007). LOPES, et al (2018) reported that the antioxidant potential of uvaia is associated with the phenolic compounds present in the fruit. These authors suggested, uvaia consumption can reduce both the oxidative stress in individuals with chronic diseases and the risk of developing cardiovascular diseases. Although, the

Table 2 - Mean concentration of phenolic compounds of the nectar formulations.

\begin{tabular}{lc}
\hline Formulation & mg galic acid. $100 \mathrm{~mL}^{-1}$ \\
\hline F1 & $108.25 \mathrm{c}$ \\
F2 & $328.80 \mathrm{~b}$ \\
\hline F3 & $405.90 \mathrm{a}$ \\
\hline
\end{tabular}

Means followed by the same letter did not differ by Tukey's test $(\mathrm{p}<0.05)$. $\mathrm{F} 1=60 \%$ orange juice; $\mathrm{F} 2=40 \%$ orange juice + $20 \%$ uvaia pulp; $\mathrm{F} 3=30 \%$ orange juice $+30 \%$ uvaia pulp. concentration of these compounds in uvaia was not investiagted in this study, the fruit has high contents of phenolic compounds, allowing the development of a beverage with health benefits.

The Brazilian Resolution RDC 12 of January 2, 2001, which regulates the sanitary microbiological standards for food, has established microbial standards only for coliforms at $35^{\circ} \mathrm{C}$ and Salmonella sp. (BRASIL, 2001). However, molds and yeasts and lactic acid bacteria counts were determined in the nectars of the present study to monitor the development of these microorganisms during the storage period.

Lactic bacteria counts were lower than 1 CFU.mL ${ }^{-1}$ for all formulations during 45 days of storage. Molds and yeasts counts were higher for the control treatment over the entire storage period, which increased at 45 days of storage for the mixed nectar containing $20 \%$ pulp (F2). The enumeration of coliforms at $35{ }^{\circ} \mathrm{C}$ was below 3.0 MPN.mL ${ }^{-1}$ for the nectars with the addition of uvaia, whereas the control treatment (F1) showed higher counts of this microrganims throughout the storage (Table 3).

Probably, the lower acidity of the nectars contributed to the development of these microorganisms in the control treatment, once no $\mathrm{pH}$ adjustment was carried out in this sample. The intrinsic characteristics of the uvaia pulp, including the higher acidity and higher concentration of phenolic compounds, conferred an inhibitory character against these microorganisms, demonstrating the technological importance of uvaia in the development of new products. 
Table 3 - Microbial counts of the nectars during the storage.

\begin{tabular}{|c|c|c|c|c|c|}
\hline & \multirow[t]{2}{*}{ Formulations } & \multicolumn{4}{|c|}{ 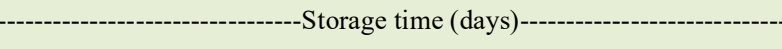 } \\
\hline & & 0 & 15 & 30 & 45 \\
\hline \multirow{3}{*}{ Lactic bacteria (CFU.mL ${ }^{-1}$ ) } & $\mathrm{F} 1$ & $<1$ & $<1$ & $<1$ & $<1$ \\
\hline & $\mathrm{F} 2$ & $<1$ & $<1$ & $<1$ & $<1$ \\
\hline & F3 & $<1$ & $<1$ & $<1$ & $<1$ \\
\hline \multirow{3}{*}{ Molds and yeasts (CFU.mL ${ }^{-1}$ ) } & $\mathrm{F} 1$ & $3.2 \times 10^{2}$ & $1.1 \times 10^{2}$ & $5.0 \times 10^{2}$ & $1.1 \times 10^{2}$ \\
\hline & $\mathrm{F} 2$ & $8.0 \times 10^{1}$ & $9.0 \times 10^{1}$ & $6.0 \times 10^{1}$ & $1.2 \times 10^{2}$ \\
\hline & F3 & $4.0 \times 10^{1}$ & $2.2 \times 10^{1}$ & $4.0 \times 10^{1}$ & $5.0 \times 10^{1}$ \\
\hline \multirow{3}{*}{ Total coliforms (MPN.mL $\left.L^{-1}\right)$} & $\mathrm{F} 1$ & $>1100$ & $<3.0$ & $>1100$ & $>1100$ \\
\hline & $\mathrm{F} 2$ & $<3.0$ & $<3.0$ & $<3.0$ & $<3.0$ \\
\hline & F3 & $<3.0$ & $<3.0$ & $<3.0$ & $<3.0$ \\
\hline
\end{tabular}

$\mathrm{CFU}=$ Colony Forming Unit; MPN = Most Probable Number; F1 = 60\% orange juice; F2 = 40\% orange juice $+20 \%$ uvaia pulp; F3 = $30 \%$ orange iuice $+30 \%$ uvaia pulp.

\section{CONCLUSION}

The findings of this study demonstrated a good physicochemical stability of all mixed nectar formulations during the storage. However, the highest microbiological stability was observed for the formulation with the addition of $30 \%$ uvaia pulp. The higher phenolic compounds and ascorbic acid levels in the mixed nectar at the end of the storage period showed a great technological potential of uvaia, which can contribute to the development of a product with relevant nutritive and bioactive properties.

\section{DECLARATION OF CONFLICT OF INTERESTS}

The authors declare no conflict of interest. The founding sponsors had no role in the design of the study; in the collection, analyses, or interpretation of data; in the writing of the manuscript, and in the decision to publish the results.

\section{AUTHORS' CONTRIBUTIONS}

All authors contributed equally to the experiment TOMAZ, K. S. and OLIVEIRA FILHO, J.H. carried out the statistical analyzes. OLIVEIRA FILHO, J.H. prepared the manuscript for submission.

\section{REFERENCES}

BEDETTI, S. de F.; et al. Néctar de cagaita (Eugenia dysenterica DC.): Desenvolvimento, caracterização microbiológica, sensorial, química e estudo da estabilidade. Boletim do CEPPA, Curitiba, v.31, n.1, p.125-138, 2013. Available from: <http://dx.doi.
org/10.5380/cep.v31i1.32709>.Accessed: Aug. 20. 2018, doi: 10.5380/cep.v31i1.32709.

BRASIL, Resolução RDC n ${ }^{\circ}$ 12, de 02 de janeiro de 2001. Aprova o Regulamento Técnico sobre os padrões microbiológicos para alimentos. Anvisa. Diário Oficial da República Federativa do Brasil. 2001.

BRASIL. Instrução Normativa $\mathrm{n}^{\circ} 42$, de 11 de setembro de 2013. Altera o art. $3^{\circ}$ da Instrução Normativa $n^{\circ} 12$, de 04 de setembro de 2003, e acrescenta o art. $3^{\circ}$ - B. MAPA. D.O.U. - Diário Oficial da República Federativa do Brasil: 2 p. 2013.

DAUD, Z. A. M. et al. Ascorbic acid: physiology and health effects. Encyclopedia of Food and Health, San Diego, p. 266-274, 2016. Available from: <https://www.sciencedirect.com/science/article/ pii/B9780123849472000453>. Accessed: Mar. 23, 2019. doi: 10.1016/B978-0-12-384947-2.00045-3.

FERREIRA, D.F. Análises estatísticas por meio do Sisvar para Windows versão 4.0. In...45 Reunião Anual da Região Brasileira da Sociedade internacional de Biometria. UFSCar, São Carlos, SP, 2000. p.255-258.

FOLIN, O.; CIOCALTEU, V. On tyrosine and tryptophane determinations in proteins. The Jornal of Biological Chemistry, Bethesda, v.73, n.2, p.627-50, 1927. Available from: $<$ http://www. jbc.org/content/73/2/627.full.pdf $>$.Accessed: May, 16, 2017. doi: content $/ 73 / 2 / 627$.

FRANCO, B. D. G. de M.; LANDGRAF, M. Microbiologia dos Alimentos. São Paulo: Atheneu, 2008, 182p.

GOMES, P. Fruticultura Brasileira. São Paulo: Nobel, 2012. 446p.

GUERRA, J. F. C. et al. Dietary açai modulates ROS production by neutrophils and gene expression of liver antioxidant enzymes in rats. Journal of Clinical Biochemistry and Nutrition, Kyoto, v.49, n.3. p.188-194, 2011. Available from: <https://www.ncbi.

Ciência Rural, v.49, n.7, 2019. 
nlm.nih.gov/pmc/articles/PMC3208015/pdf/jcbn-49-188.pdf>. Accessed: Mar. 23 , 2019.doi: 10.3164/jcbn.11-02.

INSTITUTO ADOLFO LUTZ - IAL. Métodos físico-químicos para análise de alimentos. São Paulo: Secretária de Estado da Saúde, 2008. 1020p.

KUSKOSKI, et al. Frutos tropicais silvestres e polpas de frutas congeladas: atividade antioxidante, polifenóis e antocianinas. Ciência Rural, Santa Maria, v.36, n.4. p.12831287, 2006. Available from: <http://dx.doi.org/10.1590/S010384782006000400037>. Available from: Sep. 03 , 2018. doi: $10.1590 / \mathrm{S} 0103-84782006000400037$.

LANE, J. H.; EYNON, L. Determination of reducing sugars by Fehling solution with methylene blue indicator. London: Normam Roger. 1934. 8p.

LOPES, J. M. M. et al. A preliminar exploration of the potential of Eugenia uvalha Cambess juice intake to counter oxidative stress. Food Research International, Essex, v. 105, p. 563-569, 2018. Available from: <https://doi.org/10.1016/j.foodres.2017.11.067> Accessed: Mar. 22, 2019.doi: 10.1016/j.foodres.2017.11.067.

MAIA, G. A. et al. Processamento de sucos de frutas tropicais Fortaleza: Editora UFC, 2007. 320p.

MATTIETTO, R. de. A. et al. Estabilidade do néctar misto de cajá e umbu. Ciência e Tecnologia de Alimentos, Campinas, v.27, n.3, p.456-463, 2007. Available from: <http://dx.doi.org/10.1590/ S0101-20612007000300006>. Accessed: Aug. 22, 2018. doi: 10.1590/S0101-20612007000300006

MATSUURA, F. C. A. U.; ROLIM, R. B. Avaliação da adição de suco de acerola em suco de abacaxi visando à produção de um "blend" com alto teor de vitamin C. Revista Brasileira de Fruticultura, Jaboticabal, v.24, n.1, p.138-141, 2002. Available from: $\quad<$ http://dx.doi.org/10.1590/S0100-29452002000100030>. Accessed: Apr. 04, 2018.doi: 10.1590/S0100-29452002000100030.

MORZELLE, M. C. et al. Desenvolvimento e avaliação sensorial de néctar misto de maracujá (Passiflora edulis Sims) e araticum (Annona crassiflora). Revista Brasileira de Produtos Agroindustriais, Campina Grande, v.13, n.2, p.131-135, 2011. Available from: <http://dx.doi.org/10.15871/1517-8595/rbpa. v13n2p131-135>. Accessed: Apr. 04 , 2018.doi: 10.15871/15178595/rbpa.v13n2p131-135.

NEVES, M. F. et al. O retrato da citricultura brasileira. São Paulo: CitrusBr, 2010. 137p.

NEVES, L. C. et al. Produção de blends a partir de frutos tropicais e nativos da Amazônia. Revista Brasileira de Fruticultura, Jaboticabal, v.33, n.1, p.187-197, 2011. Available from: <http:// dx.doi.org/10.1590/S0100-29452011005000023>. Accessed: Apr. 04 , 2018.doi: 10.1590/S0100-29452011005000023.
REITZ, P. et al. Projeto madeira do Rio Grande do Sul. Porto Alegre: Secretaria da Agricultura e Abastecimento. 1988. 525p.

RUFINO, M. S. M. et al. Bioactive compounds and antioxidante capacities of 18 non-traditional tropical fruits from Brazil. Food Chemistry, Barking, v.121, n.4. p.996-1002, 2010. Available from: $<$ https://doi.org/10.1016/j.foodchem.2010.01.037>. Accessed: Mar. 22, 2019.doi: 10.1016/j.foodchem.2010.01.037.

RUFINO, M. S. M. et al. Free radical-scavenging behaviour of some north-east Brazilian fruits in a DPPH system. Food Chemistry, Barking, v.114, n.2. p.693-695, 2009. Available from: $<$ https://doi.org/10.1016/j.foodchem.2008.09.098>.Accessed: Mar. 22, 2019. doi: 10.1016/j.foodchem.2008.09.098.

SANTOS, G. M. et al. Atividade antioxidante e correlações com componentes bioativos de produtos comerciais de cupuaçu. Ciência Rural, Santa Maria, v.40, n.7. p.1636-1642, 2010. Available from: <http://dx.doi.org/10.1590/S0103-84782010005000103>. Accessed: Sep. 10,2018. doi: 10.1590/S0103-84782010005000103.

SANTOS, M. V. G. et al. Elaboração de néctar misto de uva e gengibre. Brazilian Journal of Food Research, Campo Mourão, v.8, n.3, p.126-140, 2017. Available from: <https://periodicos. utfpr.edu.br/rebrapa/article/view/4464>. Accessed: Aug. 10, 2018. Doi: 10.3895/rebrapa.v8n3.4464.

SCALON, S. de P. Q. et al. Temperatura e embalagens na conservação pós-colheita de Eugenia uvalha Cambess Mirtaceae. Ciência Rural, Santa Maria, v.34, n.6, p.19651968, 2004. Available from: <http://dx.doi.org/10.1590/S010384782004000600048>.Accessed: Apr. 17 , 2018. doi: 10.1590/ S0103-84782004000600048.

SILVA, M. R. et al. Caracterização química de frutos nativos do cerrado. Ciência Rural, Santa Maria, v.38, n.6, p.1790-1793, set, 2008. Available from: <http://dx.doi.org/10.1590/S010384782008000600051>.Accessed: Abr. 17. 2018. doi: 10.1590/ S0103-84782008000600051.

SILVA, N. da. et al. A. Manual de métodos de análise microbiológica de alimentos e água. São Paulo: Blucher. 2007. 560p.

SILVA, L. M. R. et al. Quantification of bioactive compounds in pulps and by-products of tropical fruits from Brazil. Food Chemistry, Barking, v.143, p.398-404, 2014. Available from: $<$ https://doi.org/10.1016/j.foodchem.2013.08.001>. Accessed: Mar. 23 , 2019. doi: 10.1016/j.foodchem.2013.08.001.

ZILLO, R. R. et al. Qualidade físico-química da fruta in natura e da polpa de uvaia congelada. Revista Brasileira de Produtos Agroindustriais, Campina Grande, v.15, n.3, p.293-298, 2013. Available from: <http://www.deag.ufcg.edu.br/rbpa//rev153/ Art15311.pdf $>$.Accessed: Apr. 17, 2018. doi: 10.15871/15178595/rbpa.v15n3p293-298. 